\title{
Structural characterization of sulphate borophosphate glasses containing calcium oxide
}

\author{
Yamusa Abdullahi Yamusa a, b, ${ }^{*}$, Rosli Hussin a, Wan Nurulhuda Wan Shamsuri a, Sadiq \\ Abubakar Dalhatu ${ }^{\mathrm{a}}$, Aliyu Mohammed Aliyu ${ }^{\mathrm{a}}$, Ibrahim Bulus ${ }^{\mathrm{a}}$ \\ ${ }^{a}$ Department of Physics, Faculty of Science, Universiti Teknologi Malaysia, 81310 UTM Johor Bahru, Johor, Malaysia \\ ${ }^{b}$ Centre For Energy Research and Training, Ahmadu Bello University, Zaria, Nigeria \\ *Corresponding author: yamusaabdullahi@yahoo.com
}

\section{Article history}

Received 12 April 2017

Accepted 2 August 2017

Graphical abstract

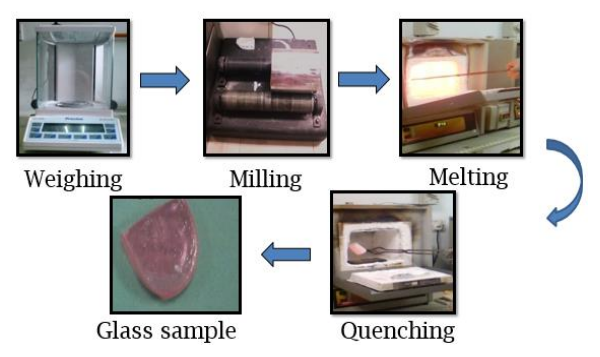

\begin{abstract}
Increasing demands for better perfoming glasses have lead to current investigating of the sturctural properties of glasses for optimum performances. Calcium sulphate borophosphate glasses of different compositions were prepared using melt quenching technique. The glass forming ability and stability were checked using Differential thermal analyzer (DTA). Density and molar volume had been evaluated and analyzed. From the results of XRD, the absent of discrete and continuous sharp peaks confirmed the amorphous nature of the glass compositions while the results from both IR and Raman revealed the existence of $\mathrm{SO}_{4}, \mathrm{BO}_{4}, \mathrm{BO}_{3}, \mathrm{P}-\mathrm{O}-\mathrm{P}$ and $\mathrm{PO}_{4}{ }^{3 .}$ . Addition of $\mathrm{CaSO}_{4}$ to borophosphate influenced the conversion of the dominant $\mathrm{BO}_{3}$ groups to $\mathrm{BO}_{4}$ groups. The structure of the samples was mainly based on metaphosphate, diphosphate and $\mathrm{BO}_{4}$ units, which became depolymerized with addition of $\mathrm{CaSO}_{4}$ content. The glass forming ability and thermal stability were found to increase with an increase in the concentration of modifier content. Glass density and molar volume is found to be between 2.146 to $2.314 \mathrm{gcm}^{-3}$ and 45.794 to $48.880 \mathrm{~m}^{3} \mathrm{~mol}^{-1}$ respectively. It is observed that the density of glass increased while the molar volume also increased with respect to increase in concentration of $\mathrm{CaSO}_{4}$ in the glass compositions. We analysed our data using different mechanisms and compared the results with previous works. Our findings show that this glass could be beneficial and considered as a good candidate for optical devices applications.
\end{abstract}

Keywords: Sulphate borophosphate glass, x-ray diffraction, differential thermal analyser, infrared and raman spectroscopy

\section{INTRODUCTION}

Borophosphate based glasses have remained the focus of numerous studies due to their unique features for diversity of applications (Karabulut et al., 2015). Glasses containing $\mathrm{B}_{2} \mathrm{O}_{3}$ are of predominant used as non-linear photonic materials and as laser hosts having high optical parameters (Srinivasulu et al., 2013) . However, unlike silicate and phosphate - based glasses, little studies have been done on borophosphate-glasses. The structural studies of borophosphate network are inspired by way of the enhancement of the glass properties. The role performed with the aid of $\mathrm{P}_{2} \mathrm{O}_{5}$ and $\mathrm{B}_{2} \mathrm{O}_{3}$ within the glass structure, and the interplay with other factors within the glass network is a motivating subject of glass technology (Pang et al., 2014). These changes in the network structure of borophosphate glasses can be sensitively detected from the changes in Raman spectra of the borophosphate glasses (Vosejpková et al., 2012). Subsequently, the mixture of the two network formers, $\mathrm{B}_{2} \mathrm{O}_{3}$ and $\mathrm{P}_{2} \mathrm{O}_{5}$ allows substantial modifications of the structural and optical properties of the materials compare to simple phosphate and borate host alone (Pang et al., 2014).For instance, the chemical durability can be increased or volume nucleation can be controlled by mixing the phosphate and borate groups. The replacement of alkali oxide with alkaline earth oxide enhances the strength of cross-linking in the glass structure (Edathazhe and Shashikala, 2016). In these glasses the basic units of pure borate glasses are trigonal $\mathrm{BO}_{3}$ groups, whereas those of pure phosphate glasses are $\mathrm{PO}_{4}$ tetrahedra linked through covalent bridging oxygen's. The addition of a modifier in some concentration ranges increases the degree of polymerization, the boron coordination changes from trigonal $\left(\mathrm{BO}_{3}\right)$ to tetrahedral $\left(\mathrm{BO}_{4}\right)$, whereas in phosphate network, an ultraphosphate network consisting of $\mathrm{Q}^{2}$ and $\mathrm{Q}^{3}$ tetrahedral (Kumar et al., 2012a).

In this present study sulphate borophosphate glasses contains calcium oxide was analyzed by melt quenching technique and the structural features of the glasses were determined using X-ray diffraction, Thermal differential analyzer, Fourier transformed infrared and Raman spectroscopy.

\section{EXPERIMENTAL}

\section{Materials}

The raw materials used for this study were $\mathrm{CaSO}_{4}$ (99.9\% purity), $\mathrm{B}_{2} \mathrm{O}_{3}$ (99.9\% purity) and $\mathrm{P}_{2} \mathrm{O}_{5}\left(99.9 \%\right.$ purity). Glasses in the $\mathrm{xCaSO}_{4}$ $30 \mathrm{~B}_{2} \mathrm{O}_{3}-(70-\mathrm{x}) \mathrm{P}_{2} \mathrm{O}_{5}$ with $15 \leq \mathrm{x} \leq 35 \mathrm{~mol} \%$ system was prepared by melt quenching technique. The homogenized samples mixture was 
poured into alumina crucible. The samples were pre-heated in an electric furnace at $300{ }^{\circ} \mathrm{C}$ for 30 minutes and then further heated at $1300{ }^{\circ} \mathrm{C}$ for $1 \mathrm{~h}$. The melts glass samples were poured onto a brass plate and annealed at $400{ }^{\circ} \mathrm{C}$ for about 3 hours to remove any internal stresses. Then, samples were allowed to cooled to room temperature. Amorphous nature of the glasses was investigated using a Bruker D8 advance diffractometer with $\mathrm{Cu}-\mathrm{K} \alpha$ radiations $(\lambda=1.54 \mathrm{~A})$ operated at $40 \mathrm{kv}$ and $100 \mathrm{~mA}$. The powder diffraction patterns were recorded on sample in the range of $2 \theta=10^{\circ}-100^{\circ}$ at scanning rate of $0.05^{\circ} / \mathrm{s}$.

The density $(\rho)$ of each sample with an error of $\pm 0.001 \mathrm{gcm}^{-3}$ was measured using Archimedes principle (Analytical balance of specific density-PrecisaXT220A) with toluene $\left(\rho_{x}=0.866 \mathrm{gcm}^{-3}\right)$ as the immersion liquid. The density of each sample is determined by the relation $\rho=\frac{W_{a}}{W_{a}-W_{b}} \rho_{x}$ where $\mathrm{W}_{\mathrm{a}}$ and $\mathrm{W}_{\mathrm{b}}$ are the sample weight in air and toluene respectively. The molar volume $\mathrm{V}_{\mathrm{m}}$ is calculated from the relation $V_{m}=\frac{M_{a v}}{\rho}$

Thermal properties of the glasses were checked using differential thermal analyzer of Perkin Elmer DTA-7 model. A sample of $11 \mathrm{mg}$ in powder form was heated at $10^{\circ} \mathrm{c} / \mathrm{min}$. The machine operated under a dry nitrogen atmosphere with flow rate of about $200 \mathrm{ml} / \mathrm{min}$. The Hruby parameter $\mathrm{H}$ is used to estimate the stability of the prepared glasses from the relation $H_{g}=\frac{T_{c}-T_{g}}{T_{m}-T_{c}}$

Fourier transform infrared transmissions spectra were recorded in the spectral range of 400 to $3500 \mathrm{~cm}^{-1}$ with Perkin Elmer FTIR 1660 spectrometer. Transparent pellets of each sample were formed by mixing a relatively fine glass powder with $\mathrm{KBr}$ at ratio 1:100.

Raman spectrum was obtained using a confocal Horbia Jobin Yvon (Model HR800 UV) in the range of $400-1500 \mathrm{~cm}^{-1}$. Argon ion laser was used as radiation source with excitation wavelength of 514.55 $\mathrm{nm}$ and power of $5 \mathrm{~mW}$.

\section{RESULTS AND DISCUSSION}

\section{X- Ray Diffraction}

Fig. 1 shows the X-ray diffraction patterns of the prepared borophosphate glasses recorded in the range of $10^{\circ}$ to $100^{\circ}$. The results obtained showed that the X-ray diffraction patterns of the sample exhibited broad diffusion at lower scattering angles around 15-25 degree. It indicated the presence of long range structural disorder and absence of any sharp peak. This result confirms that the prepared samples are completely amorphous.

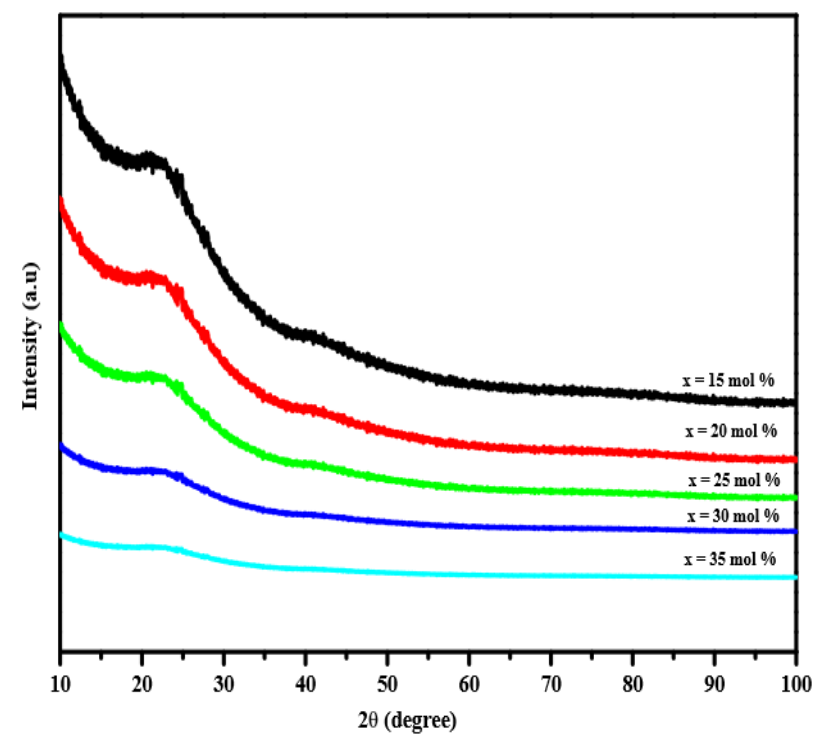

Fig.1 X-ray diffraction of $x \mathrm{xaSO}_{4}-30 \mathrm{~B}_{2} \mathrm{O}_{3}-(70-\mathrm{x}) \mathrm{P}_{2} \mathrm{O}_{5}$ with $15 \leq \mathrm{x} \leq 35$ $\mathrm{mol} \%$.

\section{Density and Molar volume measurements}

Fig. 2 depicts the variation of $\mathrm{CaSO}_{4}$ concentration plotted against density and molar volume of borophosphate glasses. The density and molar volume increases with increasing concentration of $\mathrm{CaSO}_{4}$ which indicate an increase of glass network rigidity as shown in Table 1. The increase in the glass density is due to an increase in the number of bridging oxygen in the glass (Arunkumar and Marimuthu, 2013). Furthermore, the increase in molar volume results in an increase in inter-atomic spacing or the bond length (Tanko et al., 2016).

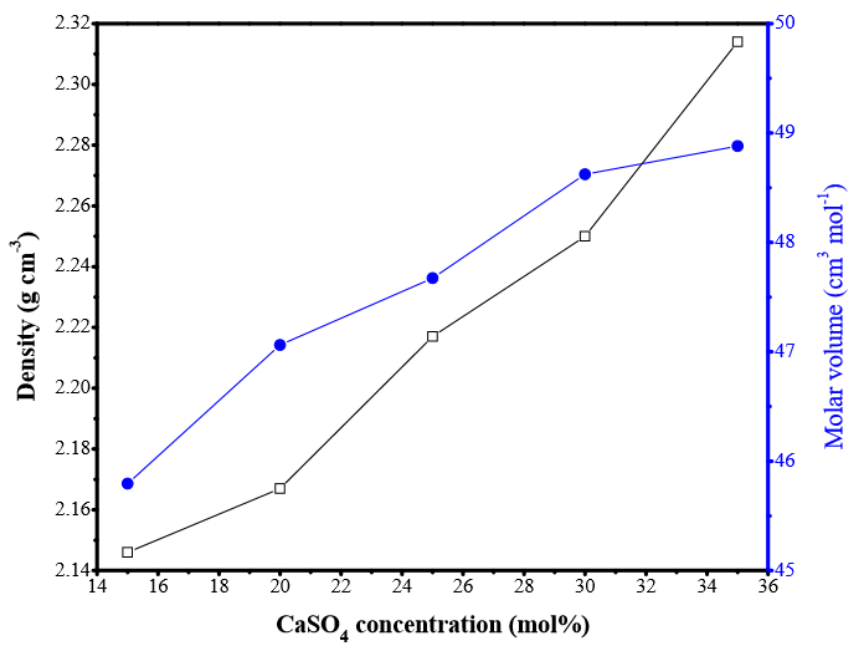

Fig. $2 \mathrm{CaSO}_{4}$ concentration dependent variation of glass density and molar volume.

Table 1 Norminal composition of $x^{2} \mathrm{CaSO}_{4}-30 \mathrm{~B}_{2} \mathrm{O}_{3}-(70-x) \mathrm{P}_{2} \mathrm{O}_{5}$ with 15 $\leq x \leq 35 \mathrm{~mol} \%$, density and molar volume of glasses.

\begin{tabular}{|c|c|c|c|c|c|}
\hline $\begin{array}{l}\text { Glass } \\
\text { code }\end{array}$ & $\begin{array}{c}\mathrm{xCaSO}_{4} \\
\mathrm{~mol} \%\end{array}$ & $\begin{array}{c}(70-\mathbf{x}) \\
\mathrm{P}_{2} \mathrm{O}_{5} \\
\mathrm{~mol} \%\end{array}$ & $\begin{array}{c}30 \\
\mathrm{~B}_{2} \mathrm{O}_{3} \\
\mathrm{~mol} \%\end{array}$ & $\rho\left(\mathrm{g} \mathrm{cm}^{-3}\right.$ & $V_{m}\left(\mathrm{~cm}^{3} \mathrm{~mol}^{-1}\right)$ \\
\hline SBP1 & 15 & 55 & 30 & 2.147 & 45.794 \\
\hline SBP2 & 20 & 50 & 30 & 2.167 & 47.062 \\
\hline SBP3 & 25 & 45 & 30 & 2.217 & 47.673 \\
\hline SBP4 & 30 & 40 & 30 & 2.250 & 48.622 \\
\hline SBP5 & 35 & 35 & 30 & 2.314 & 48.880 \\
\hline
\end{tabular}

\section{Infrared Spectra}

The results of the vibrational spectroscopy of IR gives useful structural information about the short and intermediate range in the glass structure (Stefan and Karabulut, 2014, Wan et al., 2014). In general, the main vibrational modes characteristic of atoms in the glass network are observed in the mid- IR region and these modes are independent of the other groups that may be in the glass structure (Ouis et al., 2012). Since the components investigated in this study consist of two main glass formers in different quantities, we expect to detect vibrational modes belonging to both borate and phosphate groups in the IR spectra. The IR spectra of the glasses studied in the range 400 - 3500 $\mathrm{cm}^{-1}$ frequency as shown in Fig.3. The strong band observed at 518 to $531 \mathrm{~cm}^{-1}$ assigned to bending mode of $\mathrm{PO}_{4}^{3-}$ (Karabulut et al., 2015), the band increased with increasing concentration of $\mathrm{CaSO}_{4}$. Bending of $\mathrm{B}$ O-B linkages of borate network and symmetric bending P-O-P of phosphate is around band at $735-749 \mathrm{~cm}^{-1}$ (Saitoh et al., 2015) and band at $850-889 \mathrm{~cm}^{-1}$ are assigned to the asymmetric stretching modes of the in-chain P-O-P linkages (P-O-P) as (Kumar et al., 2012b). The band at $1049-1071 \mathrm{~cm}^{-1}$ are a mixture from $v\left(\mathrm{SO}_{4}\right)$ and $v\left(\mathrm{BO}_{4}\right)$ (Daub et al., 2014) . The bands at $1260-1309 \mathrm{~cm}^{-1}$ are assigned to boroxol rings (Rada et al., 2010). The bands around 1429-1443 $\mathrm{cm}^{-1}$ have been 
assigned to the stretching relaxation of the bond between borate trigonal $\mathrm{BO}_{3}$ and oxygen units (Leow et al., 2014). Addition of $\mathrm{CaSO}_{4}$ to the glass network can alter the glass lattice, open up the network structure, lower the viscosity, weaken the bond strength of the glass and improve the glass stability (Shen et al.,2015). The variation of the spectra is due to the increase in $\mathrm{CaSO}_{4}$ content. Therefore, this variation creates larger number of non-bridging oxygen in the glass network. As a consequences of that, the phosphate coordination drastically reduces from 4-fold to 3-fold to 2-fold and even dimentional. Therefore, the depolymerization of $\mathrm{P}-\mathrm{O}-\mathrm{P}$, and $\mathrm{B}-\mathrm{O}-\mathrm{B}$ take place and strength of the glass decreases (Kumar et al., 2012c). However, it was observed that the IR intensities signifies the increase degree of disorder in the network with increase in concentration of $\mathrm{CaSO}_{4}$. The summary of IR findings and reported values are shown in Table 2.

\section{Raman Spectra}

The Raman spectra of $\mathrm{xCaSO}_{4}-30 \mathrm{~B}_{2} \mathrm{O}_{5}-(70-\mathrm{x}) \mathrm{P}_{2} \mathrm{O}_{5}$ glasses are shown in Fig. 4. The borophosphate glasses reveals one broad vibrational band in the high frequency region with a maximum at 1420 $-1424 \mathrm{~cm}^{-1}$ is due to the asymmetric stretching vibration of $\mathrm{BO}_{3}$ units
(Ganguli and Rao, 1999). The band at $1359-1361 \mathrm{~cm}^{-1}$ is due to the asymmetric stretching vibration of $\mathrm{BO}_{3}$ units (Suresh et al., 2012). The band at $1170-1179 \mathrm{~cm}^{-1}$ can be ascribed to the symmetric vibration of $\mathrm{PO}_{2}$ of metaphosphate $\mathrm{Q}^{2}$ (Kim et al., 2010). The band at $1057-1061$ $\mathrm{cm}^{-1}$ is due to the symmetric stretching vibration of the tetra hedral $\mathrm{SO}_{4}$ and $\mathrm{BO}_{4}$ units (Daub et al., 2014). The weak band at $777-780 \mathrm{~cm}^{-1} \mathrm{can}$ be ascribed to the symmetric strength vibration of $\mathrm{BO}_{3}$ and $\mathrm{BO}_{4}$ groups (Vyatchina et al., 2009). The weak band at 615-624 $\mathrm{cm}^{-1}$ can be ascribed to the vibrations of oxygen atoms in P-O-P bridges between metaphosphate $\mathrm{Q}^{2}$ and diphosphate $\mathrm{Q}^{1}$ units (Koudelka et al., 2014). The weak band located at $480-482 \mathrm{~cm}^{-1}$ can be ascribed to the bending mode vibration of $\mathrm{SO}_{4}{ }^{2-}$ (Ganguli and Rao, 1999). It was observed that a prominent and broadnening of the band at $1420-1420 \mathrm{~cm}^{-1}$ is due to the disorder glass structure (Muñoz-Martín,et al, 2009). It was observed that, by increasing the $\mathrm{CaSO}_{4}$, the vibration peaks slightly shifted to higer wavelength up to $35 \%$. This shift could indicate the effect of the $\mathrm{CaSO}_{4}$, thereby, influencing the shape of the network structure and create non-bridging oxygen resulting in the depolymerization of phosphate network (Hoppe, U.,et al, 2007). The summary of Raman findings and reported values are shown in Table 3.

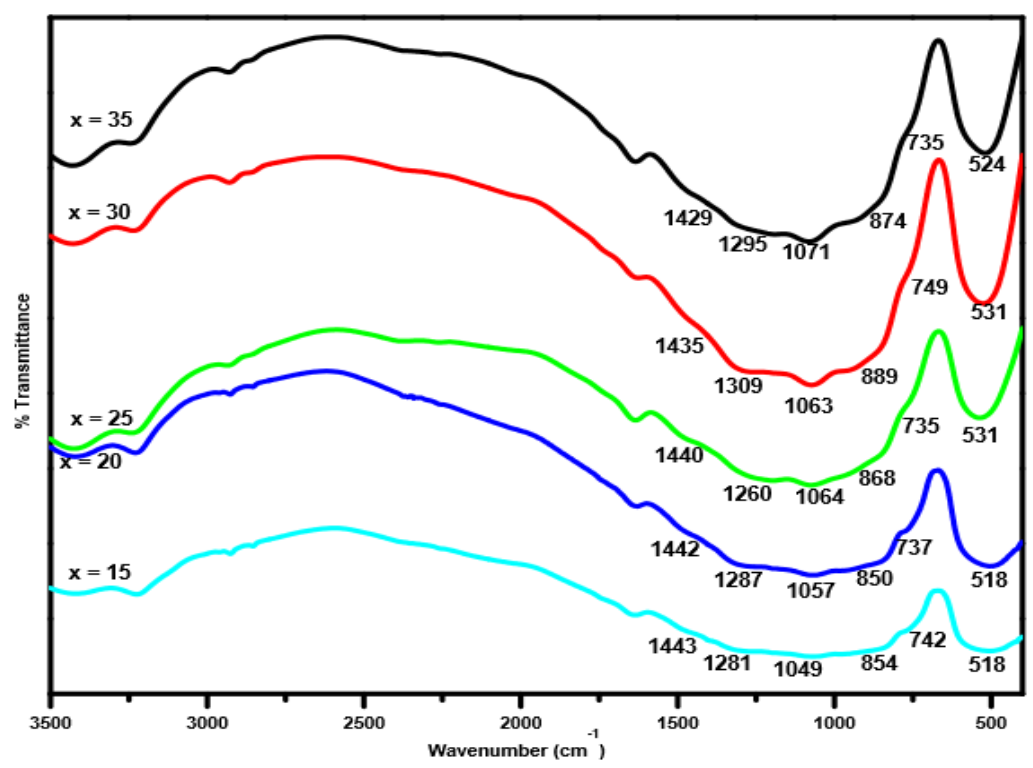

Fig.3 The IR spectra of $x \mathrm{CaSO}_{4}-30 \mathrm{~B}_{2} \mathrm{O}_{3}-(70-x) \mathrm{P}_{2} \mathrm{O}_{5}$ with $15 \leq x \leq 35 \mathrm{~mol} \%$.

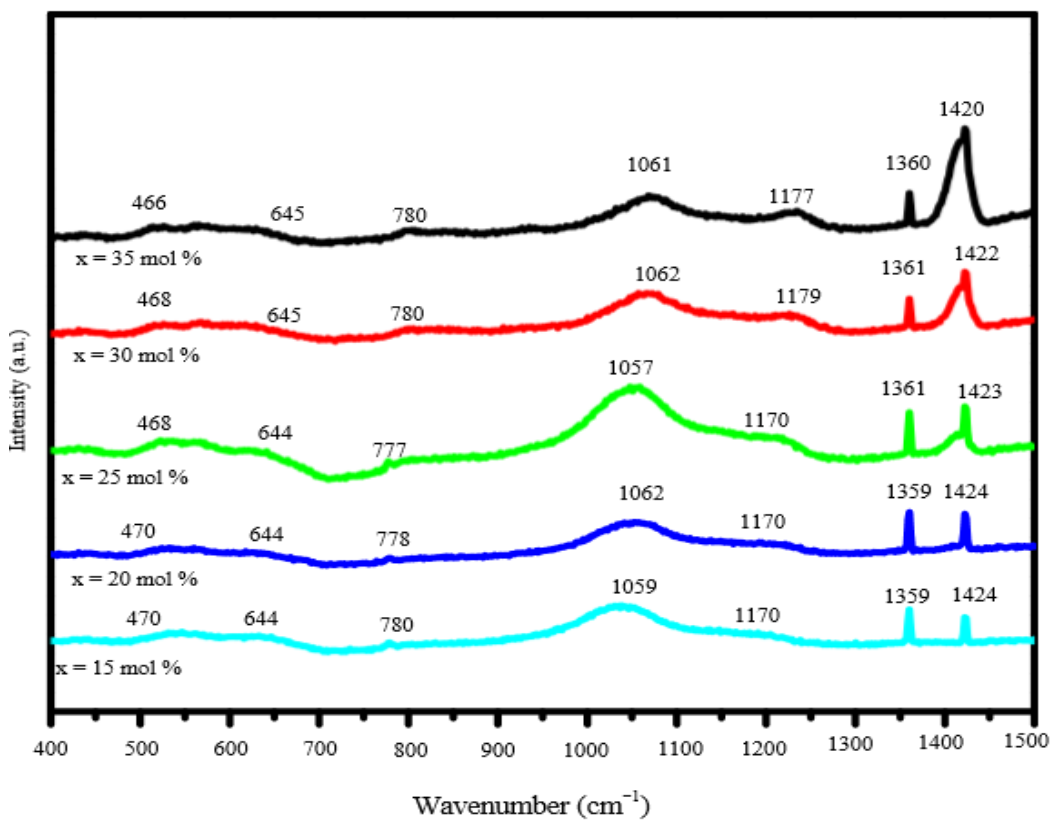

Fig.4 The Raman spectra of $x \mathrm{CaSO}_{4}-30 \mathrm{~B}_{2} \mathrm{O}_{3}-(70-x) \mathrm{P}_{2} \mathrm{O}_{5}$ with $15 \leq x \leq 35 \mathrm{~mol}$ 
Table 2 IR band assignment and the reported values for $x \mathrm{CaSO}_{4}-30 \mathrm{~B}_{2} \mathrm{O}_{3}-(70-x) \mathrm{P}_{2} \mathrm{O}_{5}$ with $15 \leq \mathrm{x} \leq 35 \mathrm{~mol} \%$ glasses.

\begin{tabular}{|c|c|c|c|c|c|c|}
\hline \multicolumn{5}{|c|}{ IR Band position in $\mathrm{cm}^{-1}$ with varying conc. of $\mathrm{CaSO}_{4}$} & \multirow{2}{*}{$\begin{array}{l}\text { Reported } \\
\left(\mathrm{cm}^{-1}\right)\end{array}$} & \multirow{2}{*}{ Assignment } \\
\hline $15(\mathrm{~mol} \%)$ & 20 (mol\%) & 25 (mol\%) & 30 (mol\%) & 35 (mol\%) & & \\
\hline 518 & 518 & 531 & 531 & 524 & $500-580$ & Bending mode of $\mathrm{PO}_{4}{ }^{3-}$ \\
\hline 742 & 737 & 735 & 749 & 735 & $745-760$ & Stretching vibration of P-O-P \\
\hline 854 & 850 & 868 & 889 & 874 & $844-964$ & Asymmetric vibration of P-O-P \\
\hline 1049 & 1057 & 1064 & 1063 & 1071 & $1060-1080$ & Mixture from $v\left(\mathrm{SO}_{4}\right)$ and $v\left(\mathrm{BO}_{4}\right)$ \\
\hline 1281 & 1287 & 1260 & 1309 & 1295 & $1240-1350$ & Boroxol rings \\
\hline 1443 & 1442 & 1440 & 1435 & 1429 & $1400-1450$ & Stretching vibration of trigonal $\mathrm{BO}_{3}$ \\
\hline
\end{tabular}

Table 3 Raman band assignment and the reported values for $x \mathrm{CaSO}_{4}-30 \mathrm{~B}_{2} \mathrm{O}_{3}-(70-x) \mathrm{P}_{2} \mathrm{O}_{5}$ with $15 \leq x \leq 35$ mol \% glasses.

\begin{tabular}{|c|c|c|c|c|c|c|}
\hline \multicolumn{5}{|c|}{ Raman Band position in $\mathrm{cm}^{-1}$ with varying conc. of $\mathrm{CaSO}_{4}$} & \multirow{2}{*}{ Reported $\left(\mathrm{cm}^{-1}\right)$} & \multirow[t]{2}{*}{ Assignment } \\
\hline $15 \mathrm{~mol} \%$ & $20 \mathrm{~mol} \%$ & $25 \mathrm{~mol} \%$ & $30 \mathrm{~mol} \%$ & $35 \mathrm{~mol} \%$ & & \\
\hline 470 & 470 & 468 & 468 & 466 & 465 & $\begin{array}{l}\text { Bending mode vibration of } \mathrm{SO}_{4}{ }^{2-} \\
\text { P-O-P bridges between }\end{array}$ \\
\hline 644 & 644 & 644 & 645 & 645 & 645 & $\begin{array}{l}\text { metaphosphate } Q^{2} \text { and diphosphate } \\
Q^{1} \text { units }\end{array}$ \\
\hline 780 & 778 & 777 & 780 & 780 & $720-780$ & $\begin{array}{l}\text { Symmetric strength vibration of } \mathrm{BO}_{3} \\
\text { and } \mathrm{BO}_{4} \text { groups }\end{array}$ \\
\hline 1059 & 1062 & 1057 & 1062 & 1061 & 1060 & $\begin{array}{l}\text { Symmetric stretching vibration of the } \\
\text { tetra hedral } \mathrm{SO}_{4} \text { and } \mathrm{BO}_{4} \text { units }\end{array}$ \\
\hline 1170 & 1170 & 1170 & 1179 & 1170 & $1165-1180$ & $\begin{array}{c}\text { Symmetric vibration of } \mathrm{PO}_{2} \text { of } \\
\text { metaphosphate } \mathrm{Q}^{2}\end{array}$ \\
\hline 1359 & 1359 & 1361 & 1361 & 1360 & $1200-1400$ & $\begin{array}{l}\text { Asymmetric stretching vibration of } \\
\qquad \mathrm{BO}_{3} \text { units }\end{array}$ \\
\hline 1424 & 1424 & 1423 & 1422 & 1429 & $1420-1485$ & $\begin{array}{l}\text { Asymmetric stretching vibration of } \\
\qquad \mathrm{BO}_{3} \text { units }\end{array}$ \\
\hline
\end{tabular}

\section{Thermal Differential Analysis}

The results of DTA measurements are shown in Fig. 5. The sharp endothermic peak is corresponding to the melting temperature $\left(\mathrm{T}_{\mathrm{m}}\right)$ at $669-702^{\circ} \mathrm{C}$, the exothermic peak is corresponding to the crystallization temperature $\left(\mathrm{T}_{\mathrm{c}}\right)$ at $519-557^{\circ} \mathrm{C}$ and the tiny peak is corresponding to the glass transition temperature $\left(\mathrm{T}_{\mathrm{g}}\right)$ at $428-438^{\circ} \mathrm{C}$. (Gilbert, J. C. \& Nocedal, J. 1992) Both the glass transition temperature and the crystallization temperature increases with an increasing $\mathrm{CaSO}_{4}$ content. Table 4 displays the values of $T_{g}, T_{c}$ and $T_{m}$ and calculated glass stability (S) and Hruby parameter for the borophosphate glasses. It was obseved that the thermal analysis depicts an increase of glass transition due to the addition of $\mathrm{B}_{2} \mathrm{O}_{3}$. This is an indication that combining $\mathrm{P}_{2} \mathrm{O}_{5}$ and $\mathrm{B}_{2} \mathrm{O}_{3}$ improves the strength of the host. The thermal Hruby parameters of SBP1 and SBP2 has been observed to be 0.6067 and 0.6225 . This falls around the limit of thermal Hruby of 0.5 as reported by (Alajerami et.al., 2012). This shows that samples SBP1 and SBP2 could be considered as the best glass former with good thermal stability among the prepared samples.

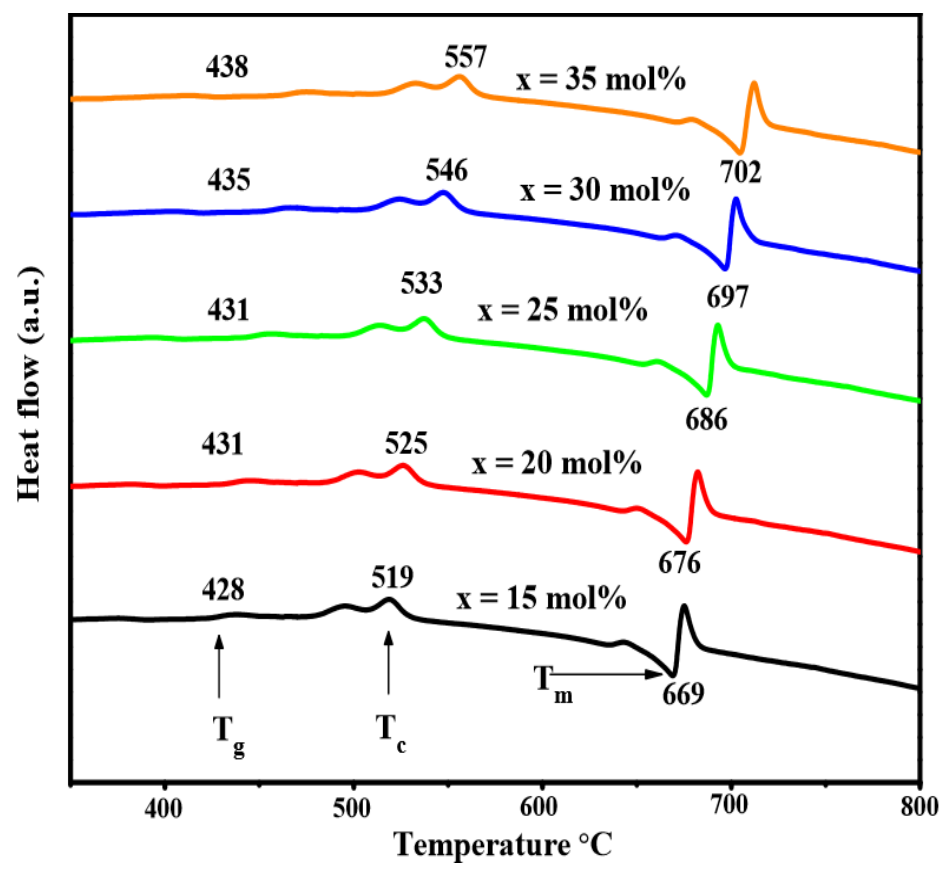

Fig. 5 The DTA spectra of $x \mathrm{CaSO}_{4}-30 \mathrm{~B}_{2} \mathrm{O}_{3}-(70-\mathrm{x}) \mathrm{P}_{2} \mathrm{O}_{5}$ with $15 \leq \mathrm{x} \leq 35 \mathrm{~mol} \%$. 
Table $4 \mathrm{CaSO}_{4}$ concentration dependent thermal properties of the prepared glasses.

\begin{tabular}{lccccc}
\hline $\begin{array}{l}\text { Glass } \\
\text { code }\end{array}$ & $\mathbf{T}_{\mathrm{g}}\left({ }^{\circ} \mathrm{C}\right)$ & $\mathbf{T}_{\mathrm{c}}\left({ }^{\circ} \mathrm{C}\right)$ & $\mathbf{T}_{\mathrm{m}}\left({ }^{\circ} \mathrm{C}\right)$ & $\begin{array}{c}\mathbf{S}=\mathbf{T}_{\mathrm{c}}-\mathbf{T}_{\mathrm{g}} \\
\left({ }^{\circ} \mathrm{C}\right)\end{array}$ & $\mathbf{H}$ \\
\hline SBP1 & 428 & 519 & 669 & 91 & 0.6067 \\
SBP2 & 431 & 525 & 676 & 94 & 0.6225 \\
SBP3 & 431 & 533 & 686 & 102 & 0.6666 \\
SBP4 & 435 & 546 & 697 & 111 & 0.7350 \\
SBP5 & 438 & 557 & 702 & 119 & 0.7986 \\
& & & & & \\
\hline
\end{tabular}

\section{CONCLUSIONS}

The structural properties of sulphate borophosphate glasses containing calcium oxide were investigated in the range $\mathrm{xCaSO}_{4}$ $30 \mathrm{~B}_{2} \mathrm{O}_{3}-(70-\mathrm{x}) \mathrm{P}_{2} \mathrm{O}_{5}$ with $15 \leq \mathrm{x} \leq 35 \mathrm{~mol} \%$ composition line. The amorphous nature of the glass is comfirmed by XRD analysis. The IR spectra of these glasses show the existence of $\mathrm{BO}_{3}, \mathrm{BO}_{4}, \mathrm{PO}_{4}{ }^{3-}, \mathrm{P}-\mathrm{O}-\mathrm{P}$ and $\mathrm{SO}_{4}$. The IR and Raman studies indicated that the increase of $\mathrm{CaSO}_{4}$ content influence significant effect of the network structure and create non-bridging oxygen. Raman spectroscopy describe the structural formation changes of stable boron and phosphorus oxygen groups with characteristics of metaphosphate and diphosphate groups. The thermal properties of sulphate borophosphate glasses such as the transition temperature, crystallisation temperature, stability and glass forming ability are determined from DTA analysis and found to be thermally stable. The stability factor (S) is found in the range of $91-$ $119{ }^{\circ} \mathrm{C}$ which indicates an increasing stability with addition of $\mathrm{CaSO}_{4}$ concentration. It is found that sample SBP1 and SBP2 have good glass forming ability and stability among the prepared glass samples. Glass density and molar volume is found to be between 2.146 to $2.314 \mathrm{gcm}^{-3}$ and 45.794 to $48.880 \mathrm{~m}^{3} \mathrm{~mol}^{-1}$ respectively. The obtained findings may provide some useful information towards the development of sulphate borophosphate glasses based solid state lasers.

\section{ACKNOWLEDGEMENT}

We are thankful to the Ministry of Higher Education Malaysia and UTM for given us financial assistance through the fundamental research grant scheme (FRGS), vote number (QJ130000.2526.10H01).

\section{REFERENCES}

Alajerami, Y. S. M., Hashim, S., Hassan, W. M. S. W. and Ramli, A. T. 2012 The effect of titanium oxide on the optical properties of lithium potassium borate glass. Journal of Molecular Structure, 1026, 159-167.

Arunkumar, S., Marimuthu, K. 2013. Concentration effect of $\mathrm{Sm}^{3+}$ ions in $\mathrm{B}_{2} \mathrm{O}_{3}$ $\mathrm{PbO}-\mathrm{PbF}_{2}-\mathrm{Bi}_{2} \mathrm{O}_{3}-\mathrm{ZnO}$ glasses-structural and luminescence investigations. Journal of Alloys and Compounds, 565, 104-114.

Daub, M., Höppe, H. A. \& Hillebrecht, H. 2014. Further new borosulfates: synthesis, crystal structure, and vibrational spectra of $\mathrm{A}\left[\mathrm{B}\left(\mathrm{SO}_{4}\right)_{2}\right](\mathrm{A}=\mathrm{Na}$ $\left.\mathrm{K}, \mathrm{NH}_{4}\right)$ and the crystal structures of $\mathrm{Li}_{5}\left[\mathrm{~B}\left(\mathrm{SO}_{4}\right)_{4}\right]$ and $\mathrm{NH}_{4}\left[\mathrm{~B}\left(\mathrm{~S}_{2} \mathrm{O}_{7}\right)_{2}\right]$. Zeitschrift für Anorganische und Allgemeine Chemie, 640, 2914-2921.

Edathazhe, A. B.,Shashikala, H. 2016. Effect of $\mathrm{BaO}$ addition on the structural and mechanical properties of soda lime phosphate glasses. Materials Chemistry and Physics, 184, 146-154.

Ganguli, M., Rao, K. 1999. Studies on the effect of $\mathrm{Li}_{2} \mathrm{SO}_{4}$ on the structure of lithium borate glasses. The Journal of Physical Chemistry B, 103, 920-930.
Gilbert, J. C., Nocedal, J. 1992. Global convergence properties of conjugate gradient methods for optimization. SIAM Journal on Optimization, 2, 2142.

Hoppe, U., Brow, R. K., Tischendorf, B. C., Kriltz, A., Jóvári, P., Schöps, Hannon, A. C., 2007. Structure of titanophosphate glasses studied by X-ray and neutron diffraction. Journal of Non-Crystalline Solids, 353(18), $1802-$ 1807.

Karabulut, M., Popa, A., Borodi, G., Stefan, R. 2015. An FTIR and ESR study of iron doped calcium borophosphate glass-ceramics. Journal of Molecular Structure, 1101, 170-175.

Kim, N.-J., Im, S.-H., Kim, D.-H., Yoon, D.-K., Ryu, B.-K. 2010. Structure and properties of borophosphate glasses. Electronic Materials Letters, 6, 103106.

Koudelka, L., Rösslerová, I., Černošek, Z., Mošner, P., Montagne, L., Revel, B. 2014. The structural role of tellurium dioxide in lead borophosphate glasses. Journal of Non-Crystalline Solids, 401, 124-128.

Kumar, A. R., Rao, C. S., Krishna, G. M., Kumar, V. R., Veeraiah, N. 2012a. Structural features of $\mathrm{MoO} 3$ doped sodium sulpho borophosphate glasses by means of spectroscopic and dielectric dispersion studies. Journal of Molecular Structure, 1016, 39-46.

Kumar, A. R., Rao, C. S., Rao, N. N., Kumar, V. R., Kityk, I., Veeraiah, N. $2012 \mathrm{~b}$. Influence of valence and coordination of manganese ions on spectral and dielectric features of $\mathrm{Na}_{2} \mathrm{SO}_{4}-\mathrm{B}_{2} \mathrm{O}_{3}-\mathrm{P}_{2} \mathrm{O}_{5}$ glasses. Journal of NonCrystalline Solids, 358, 1278-1286.

Kumar, A.R., Rao, C.S., Srikumar, T., Gandhi, Y., Kumar, V.R., Veeraiah, N., 2012. Dielectric dispersion and spectroscopic investigations on $\mathrm{Na}_{2} \mathrm{SO}_{4}$ $\mathrm{B}_{2} \mathrm{O}_{3}-\mathrm{P}_{2} \mathrm{O}_{5}$ glasses mixed with low concentrations of $\mathrm{TiO}_{2}$. Journal of Alloys and Compounds, 515, pp.134-142.

Leow, T., Leong, P., Eeu, T., Ibrahim, Z., Hussin, R. 2014. Study of structural and luminescence properties of lead lithium borophosphate glass system doped with Ti ions. Sains Malaysiana, 43, 929-934.

Muñoz-Martín, D., Villegas, M. A., Gonzalo, J., Fernández-Navarro, J. M., 2009. Characterisation of glasses in the TeO 2-WO 3-PbO system. Journal of the European Ceramic Society, 29(14), 2903-2913.

Ouis, M. A., Abdelghany, A. M., Elbatal, H. A. 2012. Corrosion mechanism and bioactivity of borate glasses analogue to Hench's bioglass. Processing and Application of Ceramics, 6, 141-149.

Pang, X. G., Eeu, T. Y., Leong, P. M., Shamsuri, W., Nurulhuda, W., Hussin, R. Structural and luminescence study of rare earth and transition metal ions doped lead zinc borophosphate glasses. Advanced Materials Research, 2014. Trans Tech Publ, 280-283.

Rada, M., Rada, S., Pascuta, P., Culea, E. 2010. Structural properties of molybdenum-lead-borate glasses. Spectrochimica Acta Part A: Molecular and Biomolecular Spectroscopy, 77, 832-837.

Saitoh, A., Tricot, G., Rajbhandari, P., Anan, S., Takebe, H. 2015. Effect of $\mathrm{B}_{2} \mathrm{O}_{3} / \mathrm{P}_{2} \mathrm{O}_{5}$ substitution on the properties and structure of tin boro-phosphate glasses. Materials Chemistry and Physics, 149, 648-656.

Srinivasulu, K., Omkaram, I., Obeid, H., Kumar, A. S., Rao, J. 2013. Structural and magnetic properties of $\mathrm{Gd}^{3+}$ ions in sodium-lead borophosphate glasses. Journal of Molecular Structure, 1036, 63-70.

Stefan, R., Karabulut, M. 2014. Structural properties of iron containing calciummagnesium borophosphate glasses. Journal of Molecular Structure, 1071, 45-51.

Suresh, S., Pavani, P. G., Mouli, V. C. 2012. Esr, optical absorption, IR and Raman studies of $\mathrm{xTeO}_{2}+(70-\mathrm{x}) \mathrm{B}_{2} \mathrm{O}_{3}+5 \mathrm{TiO}_{2}+24 \mathrm{R}_{2} \mathrm{O}: 1 \mathrm{CuO}(\mathrm{x}=10,35$ and $60 \mathrm{~mol} \% ; \mathrm{R}=\mathrm{Li}, \mathrm{Na}$ and $\mathrm{K}$ ) quaternary glass system. Materials Research Bulletin, 47, 724-731.

Shen, L. F., Chen, B. J., Pun, E. Y. B., Lin, H. 2015. Sm ${ }^{3+}$-doped alkaline earth borate glasses as $\mathrm{UV} \rightarrow$ visible photon conversion layer for solar cells. Journal of Luminescence, 160, 138-144.

Tanko, Y., Sahar, M., Ghoshal, S. 2016. Prominent spectral features of $\mathrm{Sm}^{3+}$ ion in disordered zinc tellurite glass. Results in Physics, 6, 7-11.

Vosejpková, K., Koudelka, L., Černošek, Z., Mošner, P., Montagne, L., Revel, B. 2012. Structural studies of boron and tellurium coordination in zinc borophosphate glasses by 11 B MAS NMR and Raman spectroscopy. Journal of Physics and Chemistry of Solids, 73, 324-329.

Vyatchina, V., Perelyaeva, L., Zuev, M., Baklanova, I. 2009. Structure and properties of glasses in the $\mathrm{MgSO} 4-\mathrm{Na}_{2} \mathrm{~B}_{4} \mathrm{O} 7-\mathrm{KPO}_{3}$ system. Glass Physics and Chemistry, 35, 580-585.

Wan, M. H., Wong, P. S., Hussin, R., Lintang, H. O., Endud, S. 2014. Structural and luminescence properties of $\mathrm{Mn}^{2+}$ ions doped calcium zinc borophosphate glasses. Journal of Alloys and Compounds, 595, 39-45. 